\title{
Peran Korban Anak Sebagai Pemicu Terjadinya Tindak Pidana Persetubuhan
}

\author{
Akhmad Heru Prasetyo \\ hprasetyo876@gmail.com \\ Universitas Airlangga
}

\begin{abstract}
No one normally wants himself to be a victim, a target or an object of evil. But, from the side of the victim, because the situation is in the victim or because of his attitude and behavior that sometimes encourages the perpetrator to manifest his evil intentions. Criminal sanctions against perpetrators who commit crimes, especially in criminal acts of intercourse with victims of underage children should be given appropriate punishment according to their actions, however in a case there are often cases where the victim is actively provoking the crime, so the perpetrator feels trapped alone with his actions. This kind of thing is sometimes not taken into consideration by law enforcers, especially judges in criminal prosecution for perpetrators. Child victims in the decision of the Nganjuk District Court Number 285 / Pid.Sus / 2016 / PN.Njk are included in the types of victims of Provocative victims, namely those who cause stimulation of crime. These types of victims are active victims and provide opportunities for others to commit crimes. Ironically in the decision of the Nganjuk District Court Number 285 / Pid.Sus / 2016 / PN.Njk., The Panel of Judges did not consider the type of victim and the role of the victim so that a criminal act occurred. Whereas in Decision Number: 91 / Pid.Sus / 2018 / PN.NJK. including Biologically week victims, namely those who physically have weaknesses that cause them to become victims. Based on case sitting as decision Number: 91 / Pid.Sus / 2018 / PN.NJK. the victim had tried to reject the defendant's invitation, but because the victim was helpless because of his physical weakness as a woman, the defendant had freely committed sexual intercourse. The author in this case will discuss the causality of criminal acts involving children as victims? and the ratio decidied the judge's decision to consider the role of the child as a trigger for the occurrence of criminal acts of intercourse? The approach method used in the preparation of this paper is the statutory approach, the conceptual approach and the case approach. From the results of this study it was found that there is a role of children so that victims of sexual intercourse include victims who actively provoke and mobilize perpetrators to commit crimes. Therefore, it is necessary to classify the types of victims of criminal acts in order to facilitate law enforcement officials in distinguishing and qualify victims of crime into the types of victims that exist. Thus in enforcing the law, justice, benefit and legal certainty are created as the goal of law enforcement.
\end{abstract}

Keywords: Children; Criminal Victims; Copulation Acts.

\begin{abstract}
Abstrak
Tidak ada seorangpun yang secara normal menghendaki dirinya menjadi korban, sasaran ataupun obyek dari kejahatan. Tetapi, dari sisi korban, karena keadaan yang ada pada korban atau karena sikap dan perilakunyalah yang kadang mendorong pelaku mewujudkan niat jahatnya. Penjatuhan sanksi pidana terhadap pelaku yang melakukan kejahatan khususnya dalam tindak pidana persetubuhan dengan korban anak dibawah umur memang sepatutnya diberikan hukuman setimpal sesuai perbuatannya, namun demikian dalam suatu kasus sering dijumpai kasus posisi dimana korbanlah yang aktif memancing terjadinya tindak pidana yang dialaminya, sehingga pelaku merasa terjebak sendiri dengan perbuatannya. Hal hal semacam ini kadang tidak dijadikan pertimbangan bagi para penegak hukum khususnya Hakim dalam penjatuhan pidana bagi pelaku. Korban Anak dalam putusan Pengadilan Negeri Nganjuk Nomor 285/Pid.Sus/2016/PN.Njk termasuk kedalam jenis korban Provocative victims, yaitu mereka yang menimbulkan rangsangan terjadinya kejahatan. Jenis korban semacam ini merupakan korban yang aktif dan memberikan kesempatan kepada orang lain
\end{abstract}


untuk melakukan kejahatan. Ironisnya dalam putusan Pengadilan Negeri Nganjuk Nomor 285/Pid. Sus/2016/PN.Njk., Majelis Hakim sama sekali tidak mempertimbangkan jenis korban dan peran dari korban sehingga terjadi tindak pidana. Sedangkan dalam Putusan Nomor: 91/Pid.Sus/2018/PN.NJK. termasuk kedalam jenis korban Biologically week victims, yaitu mereka yang secara fisik memiliki kelemahan yang menyebabkan ia menjadi korban. Berdasarkan duduk perkara sebagaimana putusan Nomor: 91/Pid.Sus/2018/PN.NJK. korban sudah berusaha menolak ajakan terdakwa, tetapi karena korban tidak berdaya karena kelemahan fisiknya sebagai seorang perempuan, akhirnya terdakwa dengan leluasa melakukan tindak pidana persetubuhan. Penulis dalam hal ini akan membahas Kausalitas terjadinya tindak pidana yang melibatkan anak sebagai korban? dan Ratio decidendi putusan hakim dalam mempertimbangkan peran anak sebagai pemicu terjadinya tindak pidana persetubuhan? Metode pendekatan yang digunakan dalam penyusunan karya tulis ini adalah yaitu pendekatan perundang-undangan (statute approach), pendekatan konseptual (conceptual approach) dan pendekatan kasus (case approach). Dari hasil penelitian ini didapatkan bahwa ada peran anak sehingga menjadi korban dalam tindak pidana persetubuhan diantaranya korban yang aktif memancing dan menggerakan pelaku untuk melakukan tindak pidana, untuk itu perlu dilakukan penggolongan jenis korban tindak pidana dalam undang-undang supaya dapat mempermudah aparat penegak hukum dalam membedakan dan megkualifikasikan korban tindak pidana kedalam jenisjenis korban yang ada. Dengan begitu dalam menegakkan hukum tercipta keadilan, kemanfaatan dan peastian hukum sebagaimana tujuan dari penegakan hukum.

Kata Kunci: Anak; Korban Tindak Pidana;Tindak Pidana Persetubuhan.

\section{Pendahuluan}

Konsep perlindungan hukum terhadap anak secara sistemik memiliki relevansi dengan konsep perlindungan anak seperti yang diatur di dalam UndangUndang Sistem Peradilan Pidana Anak. Undang-Undang No. 11 tahun 2012 pada Penjelasannya Pasa12 huruf a, menyatakan bahwa pelindungan anak adalah yang meliputi kegiatan yang sifatnya secara langsung dan tidak langsung dari tindakantindakan yang dapat membahayakan anak baik secara fisik maupun psikis. Berdasarkan uraian tersebut, pengertian pelindungan hukum adalah hal perbuatan melindungi anak yang lemah dan belum kuat secara fisik, mental, sosial, ekonomi dan politik, untuk mendapatkan keadilan sosial yang sifatnya tidak sekedar adaptif dan fleksibel melainkan juga prediktif dan antisipatif berdasarkan hukum yang berlaku. Terjadinya tindak pidana terhadap anak tidak lepas dari peran serta anak sebagai korban tindak pidana khususnya tindak pidana persetubuhan. Korban termasuk kategori partisipatif, artinya korban memiliki peran aktif sehingga terjadi suatu tindak pidana. Pelaku melakukan suatu kejahatan dikarenakan melihat korban melakukan suatu hal yang menyebabkan timbulnya kejahatan, sehingga korban harus selalu berhati-hati agar 
tidak menjadi korban tindak pidana. ${ }^{1}$ Terhadap hal-hal yang demikian, apakah hakim akan mempertimbangkan peran aktif korban dalam terjadinya tindak pidana.untuk itu penulis akan mengulas tentang kausalitas terjadinya tindak pidana yang melibatkan anak sebagai korban dari dua putusan dari Hakim Pengadilan Negeri nganjuk yaitu putusan Pengadilan Negeri Nganjuk Nomor 285/Pid.Sus/2016/PN.Njk dan Putusan Nomor : 91/Pid.Sus/2018/PN.NJK, dua putusan tersebut menarik dianalisis karena dari kualifikasi jenis korban sangat berbeda antara putusan yang satu dengan yang lain namun hakim tidak mempertimbangkan peran korban sehingga dalam penjatuhan pidananya relatif sama.

Kausalitas Terjadinya Tindak Pidana Yang Melibatkan Anak Sebagai Korban Perlindungan Hukum Terhadapa Anak Korban Tindak Pidana Bentuk-bentuk tindak pidana kekerasan seksual (sexual violence) adalah salah satu praktek seks yang menyimpang. Praktek hubungan seksual dilakukan dengan cara-cara kekerasan dan diluar hubungan perkawinan yang dilaksanakan secara sah dan bertentangan dengan ajaran agama islam. Kekerasan dilakukan untuk membuktikan bahwa pelakunya memiliki kekuatan fisik lebih, atau mempergunakan kelebihan kekuatan fisiknya untuk melakukan aksi kejahatan. ${ }^{2}$ Kekerasan seksual adalah suatu istilah yang menunjuk pada perilaku seksual yang menyimpang dan dapat merugikan pihak korban serta merusak ketentraman di dalam masyarakat. Akibat dari kekerasan seksual mengakibatkan penderitaan bagi korban dan menimbulkan akibat serius yang membutuhkan perhatian lebih. ${ }^{3}$

Kejahatan seksual juga dapat di artikan sebagai semua bentuk tindakan yang mengakibatkan seseorang merasa terintimidasi. Selain itu, mereka juga merasa terlecehka dan kehilangan kehormatan serta harga dirinya, baik itu melibatkan kontak fisik secara langsung maupun tidak. Kejahatan seksual merupakan suatu perbuatan yang melanggar hak asasi manusia dan merupakan suatu tindak kriminal

\footnotetext{
${ }^{1}$ YuliaRena, Viktimologi Perlindungan Hukum Terhadap Korban Kejahatan (Graha Ilmu 2010).[14].

${ }^{2}$ Abdul Wahid dan Muhammad Irfan, Perlindungan Terhadap Korban Kekerasan Seksual Advokasi Atas Hak Asasi Perempuan (Refika Aditama 2011).[32].

${ }^{3}$ ibid.
} 
yang harus ditindak secara serius, serta sudah sepatutnya digolongka sebagai kejahatan melawan kemanusiaan (crime against humanity).

Maraknya kejahatan seksual yang menimpa anak, perlu mendapatkan perhatian yang serius dari pemerintah dan lingkungan sekitar. Perlindungan terhadap anak korban tindak pidana seksual khususnya tindak pidana persetubuhan harus benar-benar ditegakkan. Bentuk perlindungan tersebut sudah banyak diatur didalam undang-undang.

Perlindungan terhadap korban mencakup perlindungan yang sifatnya abstrak (tidak langsung) maupun yang konkret (langsung). Perlindungan abstrak merupakan suatu bentuk perlindungan terhadap korban yang hanya bisa dirasakan secara emosional (psikis). Sedangkan perlindungan konkret merupakan suatu bentuk perlindungan yang dapat dinikmati secara nyata, seperti halnya pemberian materi ataupun non-materi.

Hak-hak korban tindak pidana sebagimana diatur dalam ketentuan Pasal 5 ayat (1) Undang-undang Nomor 13 Tahun 2006 tentang Lembaga Perlindungan Saksi dan Korban adalah:

a. memperoleh perlindungan atas keamanan pribadi, keluarga, dan harta bendanya, serta bebas dari ancaman yang berkenaan dengan kesaksian yang akan, sedang, atau telah diberikannya;

b. ikut serta dalam proses memilih dan menentukan bentuk perlindungan dan dukungan keamanan;

c. memberikan keterangan tanpa tekanan;

d. mendapat penerjemah;

e. bebas dari pertanyaan yang menjerat;

f. mendapatkan informasi mengenai perkembangan kasus;

g. mendapatkan informasi mengenai putusan pengadilan;

h. mengetahui dalam hal terpidana dibebaskan;

i. mendapat identitas baru;

j. mendapatkan tempat kediaman baru;

k. memperoleh penggantian biaya transportasi sesuai dengan kebutuhan;

I. mendapat nasihat hukum; dan/atau

m. memperoleh bantuan biaya hidup sementara sampai batas waktu perlindungan berakhir.

Terdapat beberapa asaz dalam rangka melindungi anak yang menjadi korban tindak pidana. Menurut Dikdik M. Arif Mansyur dkk, asas-asas yang dimaksud 
untuk melindungan anak korban kejahatan adalah: ${ }^{4}$

\section{a. Asas manfaat}

Asas manfaat adalah perlindungan korban yang tidak hanya ditujukan untuk tercapainya kemanfaatan (baik materiil maupun sepiritual) bagi korban kejahatan, tetapi juga memberikan manfaat bagi masyarakat.

\section{b. Asas keadilan}

Asas keadilan adalah penerapan asas dalam rangka memberikan perlindungan terhadap korban kejahatan yang sifatnya mutlak karena hal ini dibatasi oleh rasa keadilan yang harus juga diberikan pada pelaku kejahatan.

\section{c. Asas keseimbangan}

Tujuan hukum disamping memberikan kepastian dan perlindungan terhadap kepentingan manusia, juga untuk memulihkan keseimbangan tatanan masyarakat yang terganggu menuju pada keadaan yang semula (restitution in integrum), asas keseimbangan memperoleh tempat yang penting dalam upaya pemulihan hakhak korban.

\section{d. Asas kepastian hukum}

Asas ini dapat memberikan dasar pijakan hukum yang kuat bagi aparat penegak hukum pada saat melaksanakan tugasnya dalam upaya memberikan perlindungan hukum pada korban kejahatan.

\section{Faktor Kenakalan Anak}

Terdapat banyak faktor yang dapat mengakibatkan terjadinya kenakalan anak. Faktor-faktor tersebut adalah: ${ }^{5}$

\section{Pergaulan}

Menurut Hurlock, perilaku seksual sangat dipengaruhi oleh lingkungan pergaulannya, terutama pada masa pubertas/remaja dimana pengaruh teman

\footnotetext{
${ }^{4}$ ibid.[164]

${ }^{5}$ Muhammad Arif Fadhillah Harahap, Analisis Yuridis Penerapan Hukum Pelaku Tindak Pidana Persetubuhan Terhadap Anak (2017) Jurnal Departemen Hukum Pidana Fakultas Hukum Universitas Sumatera Utara.[10]
} 
sebaya lebih besar dibandingkan orang tuanya atau anggota keluarga lain. Dengan siapa anak bergaul dapat menjadi faktor kenakalan anak.

\section{Keluarga}

Keluarga adalah lingkungan pertama dalam melakukan interaksi dan proses sosialisasi serta pembentukan sifat pribadi anak. Keluarga merupakan tempat anak belajar pertama kali tentang cinta-kasih, simpati, loyalitas, ideologi, bimbingan dan pendidikan. Keluarga adalah lingkungan yang memberikan dampak yang sangat besar dalam menentukan pembentukan sifat dan kepribadian anak serta baik buruknya perkembangan jiwa dan jasmani anak. ${ }^{6}$ Keadaan lingkungan keluarga yang tidak harmonis dan jauh dari kasih sayang adalah salah satu faktor tidak bahagianya seorang anak.

\section{Ekonomi}

Keadaan ekonomi keluarga dapat memberikan suatu dampak yang signifikan terhadap aktivitas seksual remaja. Remaja yang berasal dari keluarga dengan ekonomi golongan bawah akan berbeda dengan remaja yang berasala dari golongan atas. lebih luas.

\section{Sosial Budaya}

Perkembangan teknologi yang sangat pesat dan alat komunikasi yang semakin canggih telah mengakibatkan terjadinya perubahan sosial di dalam masyarakat. Perubahan sosial yang diakibatkan oleh bervariasinya ide-ide ekonomi, religi, dan ilmu pengetahuan mempengaruhi adat kebiasaan hidup manusia, sekaligus mempengaruhi pola-pola seks yang konvensional. ${ }^{7}$

\section{Media Massa}

Media massa memiliki suatu dampak yang sangat tinggi diantaranya, terjadinya suatu perilaku yang menyimpang dari norma-norma sosial atau nilai-nilai budaya yang ada. Pengaruh media massa seperti contohnya televisi, majalah dan internet yang di salah gunakan oleh para remaja dalam berperilaku sehari-hari,

${ }^{6}$ Kartini Kartono, Patologi Sosial 2 Kenakalan Remaja (PT Raja Grafindo Persada 1998) .[120].

${ }^{7}$ Kartini Kartono, Psikologi Wanita Jilid I (Mengenal Gadis Remaja \& Wanita Dewasa) (Mandar Maju 1992).[221]. 
seperti remaja yang sering menyaksikan tontonan budaya barat, mereka melihat perilaku seks itu menyenangkan dan dapat diterima dilingkungannya. Sehingga dari ha-hal tersebut para remaja emngikuti dan mengaplikasikan pada kehidupan mereka sehari-hari.

\section{Tipe Korban Tindak Pidana}

Seiring dengan berkembangnya ilmu viktimologi telah mengajak masyarakat untuk lebih memperhatikan posisi korban dan memilah-milah jenis-jenis korban tindak pidana sehingga mencullah beberapa jenis korban tindak pidana, diantaranya:

a Nonparticipating victims: mereka yang tidak peduli terhadap upaya penanggulangan kejahatan.

b Latent victims: mereka yang mempunyai sifat karakter tertentu sehingga cenderung menjadi korban.

c Procative victims: mereka yang menimbulkan rangsangan terjadinya kejahatan.

d Participating victims: mereka yang dengan perilakunya memudahkan dirinya menjadi korban.

e False victims: mereka yang menjadi korban karena perbuatan yang dibuatnya sendiri. ${ }^{8}$

Tipe korban tindak pidana sebagaimana dimaksud di atas, mempunyai kesamaan dengan tipe korban yang diidentifikasi berdasarkan keadaan serta status korban, yaitu sebagai berikut:

a. Unrelated victims adalah korban tindak pidana yang tidak memiliki hubungan samasekali dengan pelaku, contohnya di dalam kasus terjadinya kecelakaan pesawat. Dalam kasus ini tanggung jawab sepenuhnya terletak pada pelaku.

b. Provocative victims adalah seseorang yang secara aktif mendorong dirinya menjadi korban, seperti dalam kasus perselingkuhan, dimana korban juga sebagai pelaku.

c. Parcticipating victims adalah seseorang yang tidak melakukan perbuatan, tetapi dikarenakan sikapnya justru menyebabkan dirinya menjadi korban.

d. Biologically week victims adalah mereka yang secara fisik memiliki kelemahan sehingga menyebabkan ia menjadi korban.

e. Socially week victims adalah mereka yang memeiliki kedudukan sosial yang lemah yang menyebabkan ia menjadi korban.

f. Self victimizing victims adalah merka yang menjadi korban dikarenakan kejahatan

${ }^{8}$ Didik M. arief Mansur \& Elisatris Gultom, Urgensi Perlindungan Korban Kejahatn Antara Norma Dan Realita (Raja Grafindo persada 2007).[49]. 
yang dilakukanya sendiri, seperti korban obat bius, judi, aborsi, prostitusi. ${ }^{9}$

Melihat peran serta korban yang menyebabkan terjadinya suatu tindak pidana, Stephen Scafer menyebutka bahwa pada prinsipnya terdapat empat tipe korban, yaitu sebagai berikut: ${ }^{10}$

a. Seseorang yang tidak mempunyai kesalahan apa-apa, tetapi tetap mejadi korban (untuk tipe ini, kesalahan mutlak ada pada pelaku).

b. Korban yang dengan sadar atau tidak telah melakukan sesuatu yang dapat merangsang orang lain untuk melakukan kejahatan (untuk tipe ini, korban mempunyai andil dalam terjadinya kejahatan sehingga kesalahan terletak pada pelaku dan korban).

c. Mereka yang secara biologis dan sosial memiliki potensi menjadi korban, seperti anak-anak, orang tua, orang yang cacat fisik atau mental, orang miskin, golongan minoritas, dan sebagainya yang merupakan orang-orang yang mudah menjadi korban.

d. Korban karena ia sendiri merupakan pelaku, inilah yang dikatakan sebagai kejahatan tanpa korban. Contoh konkritnya adalah pelacuran, judi, perzinahan, merupakan beberapa kejahatan yang tergolong kejahatan tanpa korban. Pihak yang bersalah adalah korban karena ia juga sebagai pelaku.

\section{Analisis Putusan Pengadilan Negeri Nganjuk Nomor: 285/Pid.Sus/2016/PN.Njk. dan Putusan Pengadilan Negeri Nganjuk Nomor: 91/Pid.Sus/2018/PN.NJK. Putusan Pengadilan Negeri Nganjuk Nomor: 285/Pid.Sus/2016/PN.Njk.}

Duduk perkara dalam perkara yang diputus Pengadilan Negeri Nganjuk dengan terdakwa Jumiran als Angga bin Tarmuji terjadi pada hari Sabtu tanggal 5 September 2015 sekitar pukul 22.00 WIB, bertempat dirumah Mak Saedah di Dsn. Petung, Ds. Saradan, Kec. Caruban, Kab. Madiun bermula dari perkenalan terdakwa dengan saksi korban Nurul Liana Fitri yang masih berusia 16 tahun, hubungan terus berlanjut hingga terdakwa menjemput saksi korban di perempatan awar-awar, Dsn. Manggarejo, Ds. Mancon, Kec. Wilangan, Kab. Nganjuk untuk jalan-jalan dan menginap selama 2 hari di rumah Mak Saedah Dsn. Petung, Ds. Saradan, kec. Caruban Madiun. Selama menginap dirumah tersebut, terdakwa selalu merayu korban untuk melakukan hubungan layaknya suami istri (persetubuhan). Sampai akhirnya terjadilah persetubuhan antara terdakwa dan korban.

\footnotetext{
${ }^{9}$ C. Maya Indah S., Perlindungan korban suatu persepektif viktimologi dan kriminologi (Kencana 2014).[35].

${ }^{10}$ ibid. [37].
} 
Kemudian pada tanggal 19 Oktober 2015 terdakwa mengajak korban ketemuan di Pare Kediri. Setelah ketemuan, terdakwa mengajak korban ke Mojokerto selama dua hari, ke Boyolali selama dua hari, ke semarang selama 2 bulan, ke Surabaya selama 1 bulan kemudian ke Banyuwangi selama 5 bulan. Selama korban diajak pergi oleh terdakwa, terdakwa telah menyetubuhi saksi korban lebih dari satu kali. sebelum melakukan persetubuhan dengan korban, terdakwa sering membelikan pulsa dan setelah melakukan persetubuhan. Terdakwa juga pernah memberikan uang sebesar Rp. 1.000.000,-. Selain itu, sebelum terdakwa membawa lari korban, terdakwa pernah menjajikan akan menikahi korban. Ketika itu korban bertanya kepada terdakwa "ngko piye lek aku meteng" lalu terdakwa menjawab " meteng yo beneran to malah langsung tak rabi" sehingga korban percaya dan mau diajak melakukan persetubuhan dan bersedia diajak pergi kemana-mana oleh terdakwa.

Atas perbuatan terdakwa tersebut orang tua korban tidak terima dan melaporkan ke Polsek Wilangan. Untuk kepentingan penyidikan, korban di bawa ke Rumah Sakit Bhayangkara Nganjuk untuk dimintakan Visum et Repertum dan sesuai dengan hasil Visum et Repertum No. R/24/IX/2015/Rumkit tanggal 22 September 2015 yang dibuat oleh dr GARIDAZUARISA dengan hasil pemeriksaan:

- Pemeriksaan fisik : tidak tampak kelainan dan tanda-tanda kekerasan.

- Pemeriksaan alat kelamin: Pada hymen (selaput dara) terdapat luka robek lama tidak beraturan arah jam satu, dua, empat, tujuh, sebelas dan dua belas.

\section{Pertimbangan Hakim}

- Majelis Hakim dalam persidangan ini membuktikan dakwaan alternative Penuntut Umum yang tepat untuk dapat dibuktikan dari perbuatan Terdakwa yaitu pasal 81 Ayat (2) UU RI No. 35 Tahun 2014 tentang Perubahan atas UU RI No.23 Tahun 2002 tentang Perlindungan Anak dimana unsur-unsur dari pasal tersebut adalah sebagai berikut :

1. Barang Siapa;

2. Dengan Sengaja Melakukan Tipu Muslihat, Serangkaian Kebohongan, atau Membujuk anak untuk melakukan Persetubuhan Dengannya;

- Menimbang, bahwa untuk dapat dikenakan ketentuan menurut perumusan 
Pasal 81 ayat (2) UU RI No. 35 Tahun 2014 tentang Perubahan atas UU RI No. 23 Tahun 2002, diisyaratkan perbuatan terdakwa yang dilakukan haruslah memenuhi semua unsur tersebut diatas secara akumulatif ;

\section{Unsur barang Siapa}

- Menimbang, bahwa yang dimaksud Barang Siapa adalah siapa saja yang memenuhi kriteria sebagai “orang” sebagai subjek yang hukum yang dalam kesehariannya sehat jasmani dan rohani, tidak dalam pengecualian hukum dimana semua tindakannya dapat dipertanggung jawabkan kepadanya;

- Menimbang, bahwa dalam persidangan ini, Jaksa Penuntut Umum telah mengajukan seorang terdakwa bernama Jumiran als Angga bin Tarmuji dan setelah dicocokkan dengan identitas terdakwa ternyata bersesuaian dengan identitas terdakwa dalam dakwaan Jaksa Penuntut Umum, dengan demikian tidak terjadi kesalahan orang yang diajukan sebagai terdakwa;

- Menimbang, bahwa dalam persidangan ternyata terdakwa dapat menjawab dengan lancar semua pertanyaan yang diajukan kepadanya sehingga oleh karenanya Hakim menilai jika terdakwa tidak sedang terganggu jiwanya, serta dalam keadaan sehat jasmaninya dan oleh karenanya semua perbuatannya dapat dipertanggung jawabkan kepadanya atau tidak dalam pengecualian hukum;

- Menimbang, bahwa oleh karenanya unsur Barang Siapa telah terbukti secara sah dan meyakinkan;

\section{Dengan sengaja Melakukan Tipu Muslihat, Serangkaian Kebohongan, atau} Membujuk anak untuk melakukan Persetubuhan Dengannya

- Menimbang, bahwa dengan sengaja dilakukan terdakwa Jumiran als Angga bin Tarmuji karena dilandasi rasa kesadaran penuh (bukan culpa) karena terdorong oleh napsu sehingga terdakwa melakukan perbuatan yang seharusnya tidak boleh dilakukan;

- Menimbang, bahwa unsur kedua ini merupakan unsure alternative dimana cukup satu perbuatan terbukti maka Majelis Hakim tidak perlu membukikan unsure elemen yang lain; 
- Menimbang, bahwa berdasarkan serangkaian keterangan para saksi, keterangan Terdakwa, surat serta barang bukti yang diajukan didalam persidangan ini maka dapatlah diketahui bahwa Terdakwa pada pada hari pada hari Jum'at tanggal 4 September 2015 sekira pukul 12.30 WIB terdakwa menjemput saksi korban di perempatan awar-awar, Dsn. Manggarejo, Ds. Mancon, Kec. Wilangan lalu saksi korban diajak ke warung Mak saedah setelah itu menginap selama 2 hari di rumah Mak Saedah Dsn. Petung, Ds. Saradn, kec. Caruban Madiun ketika menginap pada tanggal 5 September 2015 sekira pukul 22.00 WIB terdakwa telah menyetubuhi saksi korban dan paginya terdakwa memberi uang saksi korban sebesar Rp 10.000,- untuk naik bus;

- Menimbang, bahwa yang kedua pada tanggal 19 Oktober 2015 terdakwa mengajak saksi korban ketemuan di pare kediri setelah itu terdakwa mengajak saksi korban ke Mojokerto selama dua hari, ke Boyolali selama dua hari, ke semarang selama 2 bulan dan terdakwa telah menyetuhi saksi korban didekat Rumah Sakit Karyadi, kemudian ke Surabaya selama 1 bulan kemudian ke banyuwangi selama 5 bulan dan telah mengontrak rumah ditempat tersebut telah menyetubuhi saksi korban berkali-kali;

- Menimbang, Bahwa terdakwa menyetubuhi saksi korban dengan cara ketika terdakwa dan saksi korban sedang tidur dan saling berpelukan dan berciuman lalu terdakwa meraba payudara dan kemaluan saksi korban setelah itu terdakwa melepas seluruh pakaian yang dikenakan saksi korban dan terdakwa juga melepas seluruh pakaiannyalalu terdakwa menindih tubuh saksi korban lalu memasukkan kemaluannya kedalam vagina saksi korban lalu digerak-gerakkan naik turun hingga kemaluan terdakwa mengeluarkan prema yang dikeluakan diperut saksi korban;

- Menimbang, bahwa sebelum melakukan persetubuhan dengan saksi korban terdakwa sering membelikan pulsa dan setelah melakukan persetubuhan terdakwa pernah memberikan uang sebesar Rpn 1.000.000,- sebelum terdakwa membawa lari saksi korban;

- Menimbang, bahwa terdakwa pernah menjajikan akan menikahi saksi korban 
ketika itu saksi korban bertanya kepada terdakwa "ngko piye lek aku meteng" lalu terdakwa menjawab " meteng yo beneran to malah langsungg tak rabi" dan saksi korban percaya sehingga mau diajak pergi kemana-mana;

- Menimbang, bahwa berdasarkan Kutipan Akta Kelahiran yang ditandatangani oleh Kepala Dinas Kependudukan, dan Catatan Sipil Daerah Kabupaten Madiun Kutipan Akta kelahiran No. 000.1/UM/001U/2000 yang menerangkan bahwa NURUL LIANA FITRI lahir pada tanggal 9 Desember 1999 sehingga pada saat kejadiaan saksi korban NURUL LIANA FITRI masih berusia dibawah 18 (delapan belas) tahun;

- Menimbang, bahwa sesuai dengan hasil Visum et Repertum No. R/24/ IX/2015/Rumkit tanggal 22 September 2015 yang dibuat oleh dr GARIDA ZUARISA dengan hasil pemeriksaan:

Pemeriksaan fisik: Tidak tampak kelainan dan tanda-tanda kekerasan.

Pemeriksaan alat kelamin: Pada hymen (selaput dara) terdapat luka robek lama tidak beraturan arah jam satu, dua, empat, tujuh, sebelas dan dua belas;

\section{Kesimpulan:}

1. Telah dilakukan pemeriksaan terhadap seorang perempuan berumur kurang lebih enam belas tahun.

2. Pada pemeriksaan alat kelamin didapatkan, Pada hymen (selaput dara) terdapat luka robek lama tidak beraturan arah jam satu, dua, empat, tujuh, sebelas dan dua belas.

- Menimbang, bahwa berdasarkan hal tersebut diatas maka dapat diketahui dari apa yang sudah dilakukan oleh Terdakwa terhadap korban dimana perbuatan tersebut dilakukan oleh Terdakwa dengan penuh kesadaran dengan cara membujuk korban sehingga membuat korban terbujuk dan memenuhi keinginan Terdakwa untuk melakukan perbuatan bersetubuh;

- Menimbang, bahwa dengan demikian unsur ini telah terpenuhi pada perbuatan terdakwa;

- Menimbang bahwa berdasarkan semua pertimbangan tersebut, maka Majelis Hakim telah dapat membuktikan seluruh unsur - unsur dari Pasal dakwaan 
alternative Pertama Penuntut Umum, sehingga Mejelis Hakim berpendapat bahwa Terdakwa telah dapat terbukti secara sah dan menyakinkan melakukan tindak pidana yang didakwakan kepadanya, yaitu Dengan Sengaja Membujuk Anak Melakukan Persetubuhan Dengannya sebagaimana dalam dakwaan alternative pertama Penuntut Umum;

- Menimbang, bahwa dari kenyataan yang diperoleh selama persidangan dalam perkara ini, Majelis Hakim tidak menemukan hal-hal yang dapat melepaskan Terdakwa dari pertanggungan jawaban pidana, baik sebagai alasan pembenar dan atau alasan pemaaf, oleh karenanya Majelis Hakim berkesimpulan bahwa perbuatan yang dilakukan Terdakwa haruslah dipertanggung jawabkan kepadanya;

- Menimbang, bahwa oleh karena Terdakwa mampu bertanggung jawab, maka Terdakwa harus dinyatakan bersalah atas tindak pidana yang didakwakan kepadanya, dan oleh karena itu harus dijatuhi pidana;

- Menimbang, bahwa pidana yang akan dijatuhkan kepada Terdakwa adalah pidana penjara dimana mengenai lamanya pemidanaan akan ditentukan didalam Amar Putusan ini;

- Menimbang, bahwa karena pidana dalam ketentuan pasal 81 Ayat (2) UU RI No. 35 Tahun 2014 tentang Perubahan atas UU RI No.23 Tahun 2002 tentang Perlindungan Anak bersifat kumulatif yakni pidana penjara dan denda, maka khusus pidana denda, diterapkan ketentuan pasal 30 KUHP;

- Menimbang, bahwa oleh karena Terdakwa dijatuhi pidana maka berdasarkan Pasal 22 ayat (4) KUHAP masa penangkapan dan penahanan yang telah dijalani oleh Terdakwa dikurangkan seluruhnya dari pidana yang dijatuhkan kepadanya;

- Menimbang, bahwa Terdakwa didalam perkara ini ditahan didalam tahanan Rutan dan tidak ada alasan untuk melepaskan Terdakwa dari tahanan tersebut maka terhadap Terdakwa diperintahkan untuk tetap berada didalam tahanan rutan tersebut sebagaimana yang diatur dalam Pasal 193 ayat (2) huruf b KUHAP; 
- Menimbang, bahwa mengenai barang bukti dalam perkara ini yang telah disita oleh Penyidik dari Terdakwa dan telah diajukan Penuntut Umum ke persidangan yaitu berupa 1 (satu) potong kaos dan training bertuliskan SMA Diponegoro Nganjuk warna merah; maka mengenai barang bukti tersebut, Majelis Hakim akan menetapkan statusnya dalam amar putusan ini;

- Menimbang, bahwa berdasarkan pasal 222 ayat (1) dan (2) oleh karena terdakwa dijatuhi pidana dan terdakwa sebelumnya tidak mengajukan permohonan pembebasan dari pembayaran biaya perkara, maka Terdakwa harus dibebani untuk membayar biaya perkara yang besarnya akan ditentukan dalam amar putusan ini;

- Menimbang, bahwa untuk menjatuhkan pidana terhadap diri Terdakwa, maka perlu dipertimbangkan terlebih dahulu hal-hal yang memberatkan dan yang meringankan;

- Hal - hal yang memberatkan:

1. Perbuatan Terdakwa telah merusak masa depan korban;

- Hal - hal yang meringankan:

1. Terdakwa menyesali perbuatannya dan berjanji tidak akan mengulangi per buatannya lagi;

2. Terdakwa berterus terang dan bersikap sopan selama jalannya persidangan.

- Menimbang, bahwa berdasarkan pertimbangan hal-hal yang memberatkan dan meringankan diatas serta mengingat bahwa tujuan pemidanaan bukanlah sebagai pembalasan terhadap pelaku kejahatan melainkan pada hakekatnya merupakan salah satu sarana dan upaya untuk mendidik dan menyadarkan Para terdakwa agar tidak mengulangi perbuatannya dan mencegah orang lain melakukan perbuatan serupa, oleh karena itu tinggi rendahnya pidana yang akan dijatuhkan dalam diktum putusan dibawah ini oleh Majelis dipandang telah tepat dan adil baik secara yuridis, sosiologis maupun filosofis;

- Majelis hakim dalam perkara ini telah memvonis terdakwa dengan hukuman selama 5 tahun penjara. 


\section{Putusan Pengadilan Negeri Nganjuk Nomor: 91/Pid.Sus/2018/PN.NJK. Duduk Perkara}

Terdakwa Rudi Tri Mintono Alias Babe Bin Minto, pada hari Senin, tanggal 08 Januari 2018 sekitar pukul 10.00 Wib, di sebuah rumah yang terletak di Dsn. Pengkol, Ds. Warujayeng, Kec. Warujayeng, Kab. Nganjuk telah terjadi tindak pidana dengan sengaja melakukan kekerasan atau ancaman kekerasan memaksa anak, yaitu saksi korban Prisella Ula Asfida Alma (yang masih berusia 16 tahun), untuk melakukan persetubuhan dengannya. Perbuatan terdakwa dilakukan dengan cara terdakwa Rudi Tri Mintono yang sudah berteman dengan korban kurang lebih selama 2 (dua) tahun yaitu saksi korban Prisella Ula Asfida Alma, yang masih berusia 16 (enam belas) tahun berdasarkan Kutipan Akta Kelahiran No. 11749/U/2001, pada hari Minggu, tanggal 07 Januari 2018, terdakwa bertemu dengan korban Prisella Ula Asfida Alma yang sama-sama datang ke rumah Sdri. Yuli Andriani yang terletak di Dsn. Pengkol, Ds. Warujayeng, Kec. Warujayeng, Kab. Nganjuk, karena keduanya sudah dianggap sebagai keluarga sendiri oleh Sdri. Yuli Andriani, sehingga diperbolehkan untuk menginap di rumahnya. Pada Hari Senin, tanggal 08 Januari 2018, sekitar pukul 10.00 Sdri. Yuli Andriani keluar rumah untuk menjemput anaknya pulang sekolah, sehingga dirumah Sdri. Yuli Andriani tinggal terdakwa dan korban yang berada di dalam rumah. Ketika terdakwa dan saksi korban sedang nonton TV, tiba-tiba terdakwa menyuruh korban, "SEL, AYO NENG KAMAR", tetapi korban tidak mau sehingga terdakwa langsung menarik tangan korban dan menggendongnya masuk kedalam kamar depan, setelah itu terdakwa merebahkan korban di atas tempat tidur. Setelah itu korban berkata, "RUD, ELINGO RISMA!", karena korban mengetahui jika terdakwa sudah mempunyai pacar yang bernama RISMA, tetapi terdakwa menjawab, "WES TO, GAK EROH-GAK EROH CAH E, SENG EROH IKI CUMA AKU MBEK AWAKMU TOK”, karena takut, korban berusaha menolak, namun terdakwa justru berkata, "WES TO NDANG DIBUKA, OJO BENGAK-BENGOK BEN GAK EROH WONG”. Lalu korban disuruh tidur telentang di tempat tidur dan terdakwa langsung membuka kancing dan resleting celana korban dan menurunkannya sampai ke paha, tetapi korban menarik kembali 
celananya namun terdakwa memaksa untuk menurunkannya lagi, sehingga antara korban dengan terdakwa sempat tarik-menarik celana yang dikenakan korban, hingga kemudian celana saksi korban berhasil dilepas oleh terdakwa termasuk celana dalamnya. Setelah itu terdakwa ikut berbaring di sebelah korban, sambil terdakwa melepas celananya sendiri hingga setengah telanjang, dan menindih korban. Kemudian korban berusaha menolak terdakwa dengan mencoba menepis tangan terdakwa, tetapi terdakwa justru memegang kuat tangan korban dan menahannya di atas kepala korban sehingga tidak bisa bergerak lagi. Terdakwa lalu mencium bibir dan pipi korban sambil meraba-raba payudara korban, tidak berapa lama kemudian terdakwa merasakan alat kelaminnya (penis) menegang. Selanjutnya terdakwa memasukkan alat kelaminnya ke dalam alat kelamin (vagina) korban dengan menggunakan tangannya, lalu digerakkan naik turun kurang lebih selama 5 (lima) menit, hingga terdakwa merasakan nikmat dan akan mengeluarkan cairan sperma, setelah itu terdakwa mencabut penisnya dan mengeluarkan cairan spermanya di luar vagina korban, sedangkan korban merasakan perih dan sakit pada vaginanya, tetapi terdakwa kembali memasukkan penisnya ke dalam vagina korban, saat itu tiba-tiba terdengar suara sepeda motor datang, lalu terdakwa mencabut penisnya dan menyuruh saksi segera kembali berpakaian dan keluar kamar, sebelum Sdri. Yuli Andriani mengetahui perbuatan terdakwa yang telah menyetubuhi korban.

Setelah kejadian tersebut, korban menceritakan kepada orang tuanya bahwa korban telah disetubuhi oleh terdakwa. Selanjutnya, korban bersama orang tuanya melaporkan kejadian tersebut ke pihak kepolisian. Korban Prisella Ula Asfida Alma telah dilakukan pemeriksaan Visum et Repertum, No. Rekam Medik : 10-00-99, tertanggal 25 Februari 2018, yang dibuat dan ditandatangani oleh dr. Triono, dokter yang bertugas di Polda Jatim Bidang Kedokteran dan Kesehatan RS. Bhayangkara Moestadjab Nganjuk, berdasarkan sumpah jabatan, dengan kesimpulan:

1. Telah dilakukan pemeriksaan terhadap seorang perempuan berumur kurang lebih lima belas tahun;

2. Pada pemeriksaan alat kelamin, didapatkan pada hymen (selaput dara) terdapat luka robek lama pada jam lima, tujuh, delapan, sembilan. 


\section{Pertimbangan Hakim}

Pertimbangan-pertimbangan hukum dari mejelis hakim sebagai berikut:

\section{Unsur Setiap orang}

- Menimbang, bahwa yang dimaksud dengan unsur "setiap orang" menurut Pasal 1 angka 16 Undang-undang Nomor 35 tahun 2014 adalah orang perseorangan atau korporasi;

- Menimbang, bahwa unsur "setiap orang" in casu menunjuk kepada terdakwa yang merupakan subyek hukum perseorangan yang telah diduga melakukan tindak pidana sebagaimana didakwakan oleh Penuntut Umum dalam surat dakwaannya;

- Menimbang, bahwa berdasarkan hasil pemeriksaan identitas terhadap terdakwa yang dilakukan oleh Majelis Hakim, terdakwa adalah termasuk orang perseorangan sebagaimana dimaksud yang dalam Pasal 1 angka 16 Undangundang Nomor 35 tahun 2014 dan telah membenarkan identitasnya secara lengkap sebagaimana dalam surat dakwaan dari Penuntut Umum, sehingga Majelis Hakim berpendapat bahwa terdakwa adalah benar orang yang diduga melakukan tindak pidana sebagaimana dalam surat dakwaan Penuntut Umum;

- Menimbang, bahwa berdasarkan pada pertimbangan tersebut di atas, maka menurut hemat Majelis Hakim terhadap unsur "setiap orang" telah terpenuhi menurut hukum.

\section{Dengan sengaja melakukan tipu muslihat, serangkaian kebohongan, atau} membujuk anak untuk melakukan persetubuhan dengannya atau dengan orang lain

- Menimbang, bahwa pengertian sub unsur "dengan sengaja" dalam perkara ini merujuk pada konsep kesengajaan (opzettelijke) yang secara umum maknanya meliputi arti dari istilah "menghendaki" (willen) dan "mengetahui" (wetens), dalam arti bahwa pelaku memang menghendaki terjadinya perbuatan melawan hukum serta mengetahui pula akibat yang timbul dari perbuatan tersebut;

- Menimbang, bahwa untuk memberikan penilaian hukum tentang apakah perbuatan terdakwa a quo sebagaimana didakwakan oleh Penuntut Umum 
dalam surat dakwaannya telah memenuhi sub unsur "dengan sengaja", maka Majelis Hakim terlebih dahulu akan mempertimbangkan sub unsur "melakukan tipu muslihat, serangkaian kebohongan, atau membujuk anak untuk melakukan persetubuhan dengannya atau dengan orang lain";

- Menimbang, bahwa sub unsur "melakukan tipu muslihat, serangkaian kebohongan, atau membujuk anak untuk melakukan persetubuhan dengannya atau dengan orang lain" menurut Majelis Hakim adalah bersifat alternatif, dimana terlihat adanya frase "atau" sebagai kata penghubungnya;

- Menimbang, bahwa oleh karena sub unsur "melakukan tipu muslihat, serangkaian kebohongan, atau membujuk anak untuk melakukan persetubuhan dengannya atau dengan orang lain" adaah bersifat alternatif, maka Majelis Hakim hanya akan membuktikan salah satu sub unsur dalam elemen unsur kedua dakwaan Penuntut Umum tersebut, yang mana apabila salah satu sub unsur tersebut telah terpenuhi, maka Majelis Hakim tidak akan mempertimbangkan sub unsur yang lain dalam unsur kedua dakwaan dari Penuntut Umum;

- Menimbang, bahwa yang dimaksud dengan “persetubuhan” menurut R. Soesilo adalah adanya peraduan antara anggota kemaluan laki-laki dan perempuan yang biasa dijalankan untuk mendapatkan anak, jadi anggota kemaluan lakilaki harus masuk ke dalam anggota kemaluan perempuan, sebagaimana arrest H.R. 5 Februari 1912 (R. Soesilo, Kitab Undang-undang Hukum Pidana Lengkap, Politeia, Bogor, 1976, hal 181);

- Menimbang, bahwa pada hari Sabtu, tanggal 6 Januari 2018, sekitar pukul 08.00 WIB, saksi datang ke rumah saksi Yuli Andriani di Dusun Pengkol, Kelurahan Warujayeng, Kecamatan Tanjunganom, Kabupaten Nganjuk dan menginap selama 3 (tiga) hari;

- Menimbang, bahwa pada hari Minggu, tanggal 7 Januari 2018, sekitar pukul 11.00 WIB, saksi Prisella Ula Asfida Alma datang dan juga menginap di rumah tersebut;

- Menimbang, bahwa pada hari Senin, tanggal 8 Januari 2018, sekitar pukul 10.00 WIB, saksi Yuli Andriani pergi untuk menjemput anaknya di sekolah;

- Menimbang, bahwa terdakwa kemudian mengajak saksi Prisella Ula Asfida 
Alma masuk ke dalam kamar, kemudian saksi Prisella Ula Asfida Alma bertanya, "Risma piye,beh", namun terdakwa menjawab tidak masalah karena yang mengetahuinya hanya terdakwa dan saksi Prisella Ula Asfida Alma;

- Menimbang, bahwa terdakwa kemudian membuka celana dan membuka celananya sendiri, selanjutnya terdakwa membuka celana saksi Prisella Ula Asfida Alma dan menurunkannya hingga ke paha saksi Prisella Ula Asfida Alma dan terdakwa membuka celana dalam saksi Prisella Ula Asfida Alma, kemudian terdakwa membuka celananya sendiri dan memasukkan alat kelaminnya ke dalam alat kelamin saksi Prisella Ula Asfida Alma dan menggesek-gesekannya hingga alat kelamin terdakwa mengeluarkan spermanya di luar alat kelamin saksi Prisella Ula Asfida Alma;

- Menimbang, bahwa terdakwa mengetahui saksi Prisella Ula Asfida Alma umurnya masih di bawah 18 (delapan belas) tahun;

- Menimbang, bahwa berdasarkan Visum et Repertum Rumah Sakit Bhayangkara Moestadjab Nganjuk, yang dibuat dan ditandatangani oleh dr. Triono Dengan kesimpulan pada hymen (selaput dara) terdapat luka robek lama pada jam lima, tujuh, delapan dan sembilan;

- Menimbang, bahwa terdakwa juga dipandang sengaja melakukan perbuatan tersebut karena menghendaki untuk mencapai tujuannya, yaitu kepuasan secara biologis;

- Menimbang, bahwa dengan demikian unsur kedua dakwaan Penuntut Umum telah terpenuhi secara hukum;

- Menimbang, bahwa berdasarkan pada seluruh uraian pertimbangan tersebut diatas, maka perbuatan terdakwa telah memenuhi seluruh unsur dari Pasal 81 ayat (2) UU No. 35 Tahun 2014 Tentang Perubahan atas UU No. 23 tahun 2002 tentang Perlindungan Anak, sebagaimana yang didakwakan oleh Penuntut Umum;

- Menimbang, bahwa dalam persidangan, Majelis Hakim tidak menemukan hal-hal yang dapat menghapuskan pertanggungjawaban pidana, baik sebagai alasan pembenar dan atau alasan pemaaf, maka terdakwa harus mempertanggungjawabkan perbuatannya; 
- Menimbang, bahwa oleh karena terdakwa mampu bertanggungjawab, maka harus dinyatakan bersalah dan dijatuhi pidana;

- Menimbang, bahwa dalam perkara ini terhadap terdakwa telah dikenakan penangkapan dan penahanan yang sah, maka masa penangkapan dan penahanan tersebut harus dikurangkan seluruhnya dari pidana yang dijatuhkan;

- Menimbang, bahwa oleh karena terdakwa ditahan dan penahanan terhadap terdakwa dilandasi alasan yang cukup, maka perlu ditetapkan agar terdakwa tetap berada dalam tahanan;

- Menimbang, bahwa mengenai barang bukti berupa 1 (satu) buah sprei warna pink motif bunga-bunga;

- Menimbang, bahwa untuk menjatuhkan pidana terhadap terdakwa, maka perlu dipertimbangkan terlebih dahulu keadaan yang memberatkan dan yang meringankan terdakwa:

Keadaan yang memberatkan:

- Perbuatan terdakwa telah merusak masa depan seorang anak; Keadaan yang meringankan:

- Terdakwa belum pernah dihukum;

- Terdakwa bersikap sopan selama pemeriksaan;

- Terdakwa merupakan tulang punggung ekonomi keluarganya.

Majelis hakim dalam perkara ini juga telah memvonis terdakwa dengan hukuman selama 5 tahun penjara.

Hakim mempunyai kemerdekaan untuk melaksanakan peradilan untuk menegakkan hukum dan keadilan (vide Pasal 24 angka (1) Undang-Undang Dasar 1945 Jo Pasal 1 angka (1) Undang-Undang kekuasaan Kehakiman). Diskresi merupakan kebijakan aplikatif hakim dalam membuat putusan pidana anak. Karena hukum pidana bersifat dinamis. Kitab Undang-Undang Hukum Pidana merupakan warisan hukum kolonial Belanda yang dibuat pada tahun 1881 sudah jelas ketinggalan zaman, hakim mempunyai kemerdekaan dalam membuat putusan yang berkeadilan substantif dalam peradilan pidana anak. Diskresi dapat digunakan oleh 
hakim pidana anak apabila terjadi kepentingan yang sangat mendesak atau dalam keadaan yang benar-benar darurat untuk melindungi kepentingan umum, dalam konteks ini adalah untuk perlindungan dan kepentingan anak yang terbaik. Dalam menjatuhkan putusan pidana anak, hakim harus berwawasan hukum progresif dan mempertimbangkan perkembangan hukum progresif itu dalam putusan pidana anak. Secara instuitif, apabila terjadi benturan nilai naluri, nalar, nurani, dan nala, maka nilai nala yang mempunyai nilai spiritual harus lebih dipertimbangkan dalam menjatuhkan putusan pidana anak. Demikian pula apabila terjadi legal gab antara kepastian hukum dan keadilan, maka yang harus diselamatkan adalah nilai keadilan karena apa yang sudah pasti belum menjamin nilai keadilan. Berdasarkan legal praxis, penggunaan diskresi dalam sistem peradilan pidana anak masih langkah. Hakim masih berpegang teguh pada asas ultra petita. Praktik peradilan pidana anak seperti ini akan merugikan perkembangan jiwa dan masa depan anak. Kerugian anak dapat berimbas pada kerugian negara.

Kedua putusan yang dianalisa penulis diatas, dapat dilihat apakah hakim sudah memberikan putusan yang adil atau tidak terhadap terdakwa dan korban. Apakah hakim telah benar-benar mempertimbangkan semua aspek dari unsur tindak pidana tersebut. Kasus pertama yang dianalisa penulis adalah kasus yang diputus Pengadilan Negeri Nganjuk Nomor 285/Pid.Sus/2016/PN.Njk. dengan terdakwa Jumiran Als Angga Bin Tarmuji. Apabila dilihat dari duduk perkara kasus tersebut, dapat dilihat bagaimana peran korban sampai akhirnya terjadi tindak pidana persetubuhan. Korban merupakan seorang anak yang aktif terlibat sehingga terjadi suatu tindak pidana. Seperti, dengan mudahnya korban ikut dengan terdakwa bepergian keluar kota selama waktu tertentu dan kabur dari rumah, berdasarkan jenis-jenis korban sebagaimana telah diuraikan sebelumnya di atas, korban dalam putusan ini termasuk kedalam jenis korban Provocative victims, yaitu mereka yang menimbulkan rangsangan terjadinya kejahatan. Jenis korban semacam ini merupakan korban yang aktif dan memberikan kesempatan kepada orang lain untuk melakukan kejahatan, namun hakim menjatuhkan pidana terhadap terdakwa selama 5 tahun penjara, dan vonis ini juga sama dengan yang dijatuhkan 
terhadap terdakwa Rudi Tri Mintono Alias Babe Bin Minto sebagaimana tertuang dalam Putusan Pengadilan Negeri Nganjuk Nomor 91/Pid.Sus/2018/PN.Njk padahal korban termasuk dalam kategori Biologically week victims, yaitu mereka yang secara fisik memiliki kelemahan yang menyebabkan ia menjadi korban, dari dua putusan tersebut Majelis Hakim sama sekali tidak mempertimbangkan jenis korban dan peran dari korban sehingga terjadi tindak pidana. Majelis Hakim hanya melihat dari sisi terbuktinya tindak pidana yang dilakukan oleh terdakwa tanpa melihat latar belakang terjadinya tindak pidana. Seharusnya Majelis Hakim dapat mempertimbangkan dan menganalisa hal-hal yang mengakibatkan terjadinya tindak pidana. Tidak hanya sebatas itu, hendaknya Majelis Hakim dapat memasukkan peran dari korban yang termasuk kedalam jenis korban provocative victims kedalam hal-hal yang dapat menjadi pertimbangan dalam menjatuhkan pidana terhadap terdakwa. Dengan begitu keadilan dapat tercipta.

Berbeda halnya dengan kasus yang kedua yaitu Putusan Pengadilan Negeri Nganjuk Nomor: 91/Pid.Sus/2018/PN.NJK, dalam kasus ini dapat dianalisa jenis korban termasuk kedalam jenis korban berdasarkan tipologi korban yang diidentifikasikan menurut keadaan serta status korban, yaitu sebagai berikut:

a. Unrelated victims: yaitu korban yang tidak ada hubungannya sama sekali dengan pelaku, misalnya pada kasus kecelakaan pesawat. Dalam kasus ini tanggung jawab sepenuhnya terletak pada pelaku.

b. Provocative victims: yaitu seseorang yang secara aktif mendorong dirinya menjadi korban, misalnya dalam kasus selingkuh, dimana korban juga sebagai pelaku.

c. Parcticipating victims: yaitu seseorang yang tidak berbuat akan tetapi dengan sikapnya justru mendorong dirinya menjadi korban.

d. Biologically week victims: yaitu mereka yang secara fisik memiliki kelemahan yang menyebabkan ia menjadi korban.

e. Socially week victims: yaitu mereka yang memeiliki kedudukan sosial yang lemah yang menyebabkan ia menjadi korban.

f. Self victimizing victims: yaitu merka yang menjadi korban karena kejahatan yang dilakukan sendiri, misalnya korban obat bius, judi, aborsi, prostitusi. ${ }^{11}$

Jenis korban diatas jika dihubungkan dengan kasus yang kedua adalah masuk

${ }^{11}$ C. Maya Indah S., Perlindungan korban suatu persepektif viktimologi dan kriminologi (Kencana 2014).[35]. 
kedalam jenis korban Biologically week victims, yaitu mereka yang secara fisik memiliki kelemahan yang menyebabkan ia menjadi korban. Berdasarkan duduk perkara sebagaimana putusan Nomor: 91/Pid.Sus/2018/PN.NJK. korban sudah berusaha menolak ajakan terdakwa, tetapi karena korban tidak berdaya karena kelemahan fisiknya sebagai seorang perempuan, akhirnya terdakwa dengan leluasa melakukan tindak pidana persetubuhan. Jadi dalam kasus ini, kesalahan mutlak menjadi tanggungjawab terdakwa dan Majelis Hakim sudah tepat dalam memberikan putusan kepada terdakwa.

Dalam menjatuhkan putusan kepada terdakwa, hendaknya Majelis Hakim bersikap objektif terhadap suatu perkara yang ditanganinya. Hal tersebut dikarenakan Hakim bukanlah pembuat hukum berdasarkan kehendaknya yang subjektif, melainkan hanya pekerja yang mencoba menemukan hukum yang ada, untuk menyelesaikan perkara yang diajukan kepadanya. Prosedur kerja dan metode berpikirnya tak lain ialah pendayagunaan silogisma deduksi, dan bukan emosi pemihakan, sine ira (tanpa kegalauan atau kegusaran) untuk menerima pembuktian tentang apa duduk perkaranya (premis minor), menemukan apa dasar hukumnya (premis mayor), dan menarik simpulan (conclusio) dari dua premis tersebut sebagai amar putusannya.

\section{Kesimpulan}

Penjatuhan sanksi pidana terhadap pelaku yang melakukan kejahatan khususnya dalam tindak pidana persetubuhan dengan korban anak dibawah umur memang sepatutnya diberikan hukuman setimpal sesuai perbuatannya, namun demikian dalam suatu kasus sering dijumpai kasus posisi dimana korbanlah yang aktif memancing terjadinya tindak pidana yang dialaminya, sehingga pelaku merasa terjebak sendiri dengan perbuatannya. Hal hal semacam ini kadang tidak dijadikan pertimbangan bagi para penegak hukum khususnya Hakim dalam penjatuhan pidana bagi pelaku.

Dua putusan Pengadilan Negeri Nganjuk yang sama sama memvonis terdakwa 5 tahun pidana penjara dengan kasus posisi yang berbeda setelah kami analisa Majelis Hakim sama sekali tidak mempertimbangkan jenis korban dan 
peran dari korban sehingga terjadi tindak pidana. Dari putusan Pengadilan Negeri Nganjuk Nomor 285/Pid.Sus/2016/PN.Njk Majelis Hakim hanya melihat dari sisi terbuktinya tindak pidana yang dilakukan oleh terdakwa tanpa melihat latar belakang terjadinya tindak pidana. Seharusnya Majelis Hakim dapat mempertimbangkan dan menganalisa hal-hal yang mengakibatkan terjadinya tindak pidana. Tidak hanya sebatas itu, hendaknya Majelis Hakim dapat memasukkan peran dari korban yang termasuk kedalam jenis korban Provocative victims kedalam hal-hal yang dapat menjadi pertimbangan dalam menjatuhkan pidana terhadap terdakwa. Dengan begitu keadilan dapat tercipta.

Sedangkan dalam Putusan Nomor: 91/Pid.Sus/2018/PN.NJK. termasuk kedalam jenis korban Biologically week victims, yaitu mereka yang secara fisik memiliki kelemahan yang menyebabkan ia menjadi korban. Berdasarkan duduk perkara sebagaimana putusan Nomor: 91/Pid.Sus/2018/PN.NJK. korban sudah berusaha menolak ajakan terdakwa, tetapi karena korban tidak berdaya karena kelemahan fisiknya sebagai seorang perempuan, akhirnya terdakwa dengan leluasa melakukan tindak pidana persetubuhan.

Tidak adanya pengaturan dalam undang-undang tentang penggolangan jenis korban tindak pidana, untuk itu perlu adanya pengaturan yang jelas dan tersendiri khususnya dalam RUU KUHP terkait jenis-jenis korban tindak pidana. Pengaturan penggolangan jenis korban tindak pidana didalam undangundang diharapkan dapat memberikan efek jera terhadap korban tindak pidana yang termasuk golongan Provocative victims yang berperan aktif dalam terjadinya tindak pidana. Penggolongan jenis korban tindak pidana dalam undang-undang juga dapat mempermudah penegak hukum dalam membedakan dan megkualifikasikan korban tindak pidana kedalam jenis-jenis korban yang ada. Dengan begitu pelaku tindak pidana tidak dirugikan apabila terjadinya tindak pidana karena adanya peran aktif korban. Selanjutnya, aparat penegak hukum hendaknya dalam memberikan putusan agar lebih mempertimbangkan dan memperhatikan lagi posisi korban, karena tidak semua kesalahan mutlak ada pada pelaku. Dalam menanganai perkara anak, penegak hukum harus 
lebih memperhatikan lagi undang-undang perlindungan anak serta lebih mementingkan rehabilitasi anak daripada penjatuhan pidana terhadap anak sebagaimana tujuan restoratif justice.

\section{Daftar Bacaaan}

\section{Buku}

Indah S. C. Maya, Perlindungan korban suatu persepektif viktimologi dan kriminologi (Kencana 2014).

Kartono, Kartini, Patologi Sosial 2 Kenakalan Remaja (PT Raja Grafindo Persada 1998).

Psikologi Wanita Jilid I (Mengenal Gadis Remaja \& Wanita Dewasa) (Mandar Maju 1992).

M. arief Mansur, Didik \& Elisatris Gultom, Urgensi Perlindungan Korban Kejahatn Antara Norma Dan Realita (Raja Grafindo persada 2007).

Prakoso, Bintoro, Pembaharuan Sistem Peradilan Pidana Anak (Laksbang Grafika 2012).

Rena, Yulia, Viktimologi Perlindungan Hukum Terhadap Korban Kejahatan (Graha Ilmu 2010).

Muhammad Arif Fadhillah Harahap, Analisis Yuridis Penerapan Hukum Pelaku Tindak Pidana Persetubuhan Terhadap Anak, (2017) Jurnal Departemen Hukum Pidana Fakultas HukumUniversitas Sumatera Utara.

Muladi dan Barda Nawawi Arif, Bunga Rampai Hukum Pidana (PT. Alumni 1992).

Wahid, Abdul dan Muhammad Irfan, Perlindungan Terhadap Korban Kekerasan Seksual Advokasi Atas Hak Asasi Perempuan (Refika Aditama 2011).

\section{Perundang-undangan}

Undang-Undang Dasar Negara Kesatuan Republik Indonesia1945.

Undang-Undang Nomor 1 Tahun 1946 tentang Peraturan Hukum Pidana .

Undang-Undang Nomor 73 Tahun 1958 tentang Menyatakan Berlakunya Undang.

Undang Nomor 1 Tahun 1946 Republik Indonesia tentang Peraturan Hukum Pidana 
Untuk Seluruh Wilayah Republik Indonesia dan Mengubah Kitab UndangUndang Hukum Pidana.

Undang-Undang Nomor 8 Tahun 1981 Tentang Hukum Acara Pidana.

Undang-undang Nomor 48 Tahun 2009 tentang Kekuasaan Kehakiman. (Tambahan Lembaran Negara Republik Indonesia Nomor 5076).

Undang-Undang Nomor 11 Tahun 2012 Tentang Sistem Peradilan Pidana Anak (Lembaran Negara Republik Indonesia Tahun 2012 Nomor 153, Tambahan Lembaran Negara Republik Indonesia Nomor 5332).

Undang-Undang No. 35 Tahun 2014 Tentang Perubahan Undang-Undang No. 23 Tentang Perlindungan Anak (Lembaran Negara Republik Indonesia Tahun 2014 Nomor 297, Tambahan Lembaran Negara Republik Indonesia Nomor 5606).

\section{Putusan Pengadilan}

Putusan Pengadilan Negeri Nganjuk Nomor 285/Pid.Sus/2016/PN.Njk.

Putusan Pengadilan Negeri Nganjuk Nomor:91/Pid.Sus/2018/PN.NJK.

HOW TO CITE: Akhmad Heru Prasetyo, 'Peran Korban Anak Sebagai Pemicu Terjadinya Tindak Pidana Persetubuhan' (2019) Vol. 2 No. 1 Media Iuris. 